\title{
Genetic Improvement of Lentil [Lens culinaris Medikus] Between 1980 and 2010 in Ethiopia
}

\author{
Daniel Admasu Bogale ${ }^{1 *}$, Firew Mekbib ${ }^{2}$, Asnake Fikre ${ }^{3}$ \\ ${ }^{1}$ Debre Birhan Agricultural Research Center, Debre Birhan, North Shewa, ETHIOPIA \\ ${ }^{2}$ Haramaya University, 138 Dire Dawa, ETHIOPIA \\ ${ }^{3}$ Debre Zeit Agricultural Research Center, ETHIOPIA
}

Email for Correspondence: admasudaniel@gmail.com

\begin{abstract}
Information about changes associated with advances in crop breeding is essential for understanding yield-limiting factors and developing new strategies for future breeding programs. Eleven lentil varieties released in Ethiopia between 1980 and 2010 were grown in 2010 main cropping season at Debre Zeit and Enewari using Randomized Complete Block Design with three replications with the objective to estimate the genetic progress in grain yield and agro-morphological traits of lentil. The estimated yield gains were $18.02 \mathrm{~kg} \mathrm{ha}^{-1} \mathrm{yr}^{-1}$ at Enewari and $27.82 \mathrm{~kg} \mathrm{ha}^{-1} \mathrm{yr}^{-1}$ at Debre Zeit, which suggests that the breeding effort does not have a similar effect on the two locations. Besides, significantly increasing trends parallel to variety release were also evident for biomass yield, biomass production rate, reduced days to flowering, and hundred seed weight at Debre Zeit. And also for biomass yield, hundred seed weight, biomass production rate, seed growth rate, and reduced number of seeds per pod at Enewari. Stepwise regression analysis also showed that biomass yield, harvest index, reduced number of days to flowering and plant height at Debre Zeit; seed growth rate and grain filling period at Enewari accounted for $99.8 \%$ and $94.5 \%$ of the variation among the varieties in grain yield respectively. The genetic gain was most clearly associated with a higher biomass yield and harvest index at Debre Zeit indicating the importance of biomass partitioning. The increase in seed growth rate and grain filling period with gradual reduction in number of seeds per pod associated with an increased hundred seed weight has represented the main breeding goal with an effect on the sink capacity at Enewari.
\end{abstract}

Key words: Genetic improvement, Harvest index, Seed growth rate, Stepwise regression

\section{INTRODUCTION}

Lentil (Lens culinaris Medikus) is a self-pollinated diploid $(2 \mathrm{n}=14)$ annual cool season legume crop produced throughout the world and valued as high protein food. Globally lentil is an important food legume crop component of farming and food systems of many countries (Sarker et al., 2002). Lentil has a good amino acid pattern in that it contains all the human essential amino acids sufficient in proportions as recommended by the World Health Organization (Grusak, 2009). The exceptions are the sulfur-containing amino acids, methionine, and cysteine, which (as with most legume seeds) are the most limited amino acids. On the contrary, lentil has adequate to high levels of lysine. This is why lentils are suggested as ideal complementary foods to cereals (rice, wheat, maize), which are low in lysine and generally better sources of the sulfur amino acids (Shewry and Halford, 2002).

Globally lentil productivity was only $560 \mathrm{~kg} / \mathrm{ha}$ during the period 1961-1963 and reached $950 \mathrm{~kg} / \mathrm{ha}$ by 2004-2006 (Erskine, 2009). In Ethiopia, Lentils currently covers an area of about 105,956.04 hectares with an annual production 
volume of $1,237,772$ quintal; the national average productivity being about 11.68 quintals/ha (CSA, 2010). They are mostly cultivated for domestic consumption. However the demand and request for both grain and split red cotyledon is very high in India, Lebanon and Srilanka.

The Ethiopian National Agricultural Research System in collaboration with ICARDA has so far released eleven lentil varieties since 1980. A successful breeding program is likely to generate genetic gain in yield overtimes that is one component of grain yield potential (Heisey et al., 2002). Genetic improvement can be studied either by estimating level of genetic advance from a single or a series of selection cycles made at a time or from a long-term breeding effort made by a breeding program (Waddington et al., 1986). Likewise, estimation of genetic progress from a breeding program and periodic evaluation of advancement in the genetic gain of a crop is required to understand changes produced by breeding activities, to assess the efficiency of past improvement works in genetic yield potential and suggest on future selection direction to facilitate further improvement and fulfill farmers need in seed and grain production. Progress made in genetic yield potential and associated traits produced by different crops improvement program was evaluated and documented in Ethiopia. They all concluded that genetic improvement in those crops have produced modern cultivars with improved yield potential (Amsal, 1995a and b; Yifru and Hailu, 2005; Kebere et al., 2006). However, there was no study conducted to determine the genetic gain in grain yield potential and associated traits in lentil in Ethiopia. Hence, the study was initiated with the following objectives:

- To estimate the genetic progress made in improving the yield potential of lentil varieties.

- To assess changes in associated traits in the genetic improvement of lentil varieties released in Ethiopia.

\section{Materials AND Methods}

The experiment was conducted at Debre Zeit and Enewari, during the main cropping season of 2010. The locations are testing sites of Debre Zeit Agricultural Research Center and Debre Birhan Agricultural Research Center, respectively. The soil type of the experimental sites at both locations is classified as Vertisol with clay loam texture. The experiment was conducted using eleven lentil varieties released between 1980 and 2010. The seed of the varieties was obtained from Debre Zeit and Sinana Agricultural research Centers, with varietal description indicated in Table 1 below.

Table 1: Description of released lentil varieties

\begin{tabular}{|l|l|c|}
\hline Variety & Source & Year of release \\
\hline El-142 & Ethiopia & 1980 \\
\hline R-186 & ICARDA & 1980 \\
\hline Chalew & ICARDA & 1984 \\
\hline Chekol & ICARDA & 1984 \\
\hline Gudo & ICARDA & 1995 \\
\hline Adaa & ICARDA & 1995 \\
\hline Alemaya- 98 & ICARDA & 1997 \\
\hline Assano & ICARDA & 2003 \\
\hline Alemtena & ICARDA & 2004 \\
\hline Teshale & ICARDA & 2004 \\
\hline Derso & ICARDA & 2010 \\
\hline
\end{tabular}

The experiment was conducted in Randomized Complete Block Design (RCBD) with three replications. A plot consisting four rows of $4 \mathrm{~m}$ long by 0.8 widths $\left(3.2 \mathrm{~m}^{2}\right)$ with spacing of $0.2 \mathrm{~m}$ between rows, $0.4 \mathrm{~m}$ between plots and $1.5 \mathrm{~m}$ between blocks was used. A seed rate of 200 seeds was administered to each row. The experiment was planted on July 30, 2010, at Debre Zeit and August 9, 2010, at Enewari. Throughout the experimental period, plots were made free of weeds using hand weeding. At Enewari, Dimethoate $40 \mathrm{EC}$ insecticide was sprayed at the rate of one liter ha ${ }^{-1}$ in 200 liters of water to control pea aphid. Maximum care was taken to the experiment to minimize the possible occurrence of yield-limiting factors that could affect yield potential performance of the varieties. Besides, all pertinent field trial management practices were implemented with strict, close supervision.

To estimate difference among the varieties all measured variables were subjected to analysis of variance (ANOVA) using SAS software version 9.00 (SAS Institute, 2004). Variance ratio test for homogeneity of variance was carried out to determine the validity of the individual experiment. Log transformation was used for those traits, which exhibited heterogeneity of variance, grain yield, and days to maturity, number of secondary branches, and number of seeds per pod, number of pod per plant, biomass production rate, and seed growth rate. The data on harvest index were 
transformed by arcsine. However, the transformation could not stabilize homogeneity of variance for all the above traits. Consequently, data set from Debre Zeit and Enewari were treated separately.

Analyses of variance for each location executed following the standard procedure given by Gomez and Gomez (1984). Mean separation was carried out using Duncan's Multiple Range Test at 5\% of significance. Linear regression analysis was used to calculate the genetic gain for each trait considered in the study. The breeding progress was estimated as a genetic gain for grain yield and associated agronomic traits by regressing mean of each character at each location for each variety against the year of release of that variety. The relative gain achieved over the 30 years release period for traits under consideration were determined as a ratio of genetic gain to the corresponding mean value of oldest variety and expressed as a percentage. Pearson product moment correlation coefficients for grain yield and all other traits were computed using mean performance of each variety. A stepwise regression analysis was carried out on the varietal mean, to determine those variables contributing much to yield variation using PROC REG procedure.

\section{RESULTS}

The results of the separate analysis of variance for the two individual locations for grain yield $\left(\mathrm{kg} \mathrm{ha}^{-1}\right)$ showed a highly significant difference among varieties at Debre Zeit and Enewari (Table 2).The mean grain yield of all lentil varieties was $1304.74 \mathrm{~kg} \mathrm{ha}^{-1}$ and $2493.9 \mathrm{~kg} \mathrm{ha}^{-1}$ at Debre Zeit and Enewari, respectively (Table 3). At Enewari the recently released variety, 'Derso', showed a significant $(\mathrm{P}<0.05)$ higher grain yield than all the other varieties tested except Alemaya, Assano, and Alemtena. Whereas, at Debre Zeit this variety gave a significant higher grain yield than all the varieties except variety Teshale, and Alemaya (Table 3). The grain yield increment of varieties derived from introduction over that of derived from the local collection (El-142) was $78.24 \%$ at Debre Zeit and $10.44 \%$ at Enewari.

Table 2: Mean square values of characters from the separate analysis of variance for lentil varieties grown in the yield potential trial at Enewari and Debre Zeit

\begin{tabular}{|l|c|c|c|c|}
\hline \multirow{2}{*}{} & \multicolumn{3}{|c|}{ Source of Variation } \\
\cline { 2 - 5 } & \multicolumn{2}{|c|}{ Enewari } & \multicolumn{2}{c|}{ Debre Zeit } \\
\hline Characters & Variety (10) & Error (20) & Variety (10) & Error (20) \\
\hline Days to flowering & $31.763^{* *}$ & 3.427 & $170.497^{* *}$ & 2.361 \\
\hline Days to maturity & $34.000^{* *}$ & 0.718 & $129.685^{* *}$ & 5.485 \\
\hline Grain filling period & 4.097 & 2.47 & $51.939^{* *}$ & 6.339 \\
\hline Primary branch & 0.069 & 0.051 & $0.198^{*}$ & 0.074 \\
\hline Secondary branch & $8.069^{* *}$ & 0.214 & $36.383^{*}$ & 12.003 \\
\hline Plant height & $42.343^{*}$ & 13.968 & 21.632 & 9.989 \\
\hline Seed per pod & $0.095^{*}$ & 0.0334 & 0.223 & 0.209 \\
\hline Pod per plant & $233.56^{*}$ & 72.61 & $1078.017^{*}$ & 440.966 \\
\hline Hundred seed weight & $1.962^{* *}$ & 0.0323 & $2.093^{* *}$ & 0.081 \\
\hline Grain yield & $191554.55^{* *}$ & 54669.784 & $703708.79^{* *}$ & 184133 \\
\hline Biomass yield & $929861.76^{* *}$ & 190670.55 & $2125479.57^{*}$ & 494688.17 \\
\hline Harvest index & $0.0052^{* *}$ & 0.0009 & $0.0122^{*}$ & 0.0056 \\
\hline Biomass production rate & $84.194^{* *}$ & 17.295 & $242.736^{* *}$ & 58.915 \\
\hline Grain growth rate & $90.465^{* *}$ & 23.283 & $391.574^{* *}$ & 106.59 \\
\hline
\end{tabular}

*, ** Mean squares of characters were significant at probability of 0.05 and 0.01 , respectively. Numbers in parenthesis represent degree of freedom.

The average rate of increase in grain yield potential per year of release over the 30 year period was $27.82 \mathrm{~kg} \mathrm{ha}^{-1}$ at Debre Zeit (Fig.1A) and 18.02 at Enewari (Fig. 1B). 

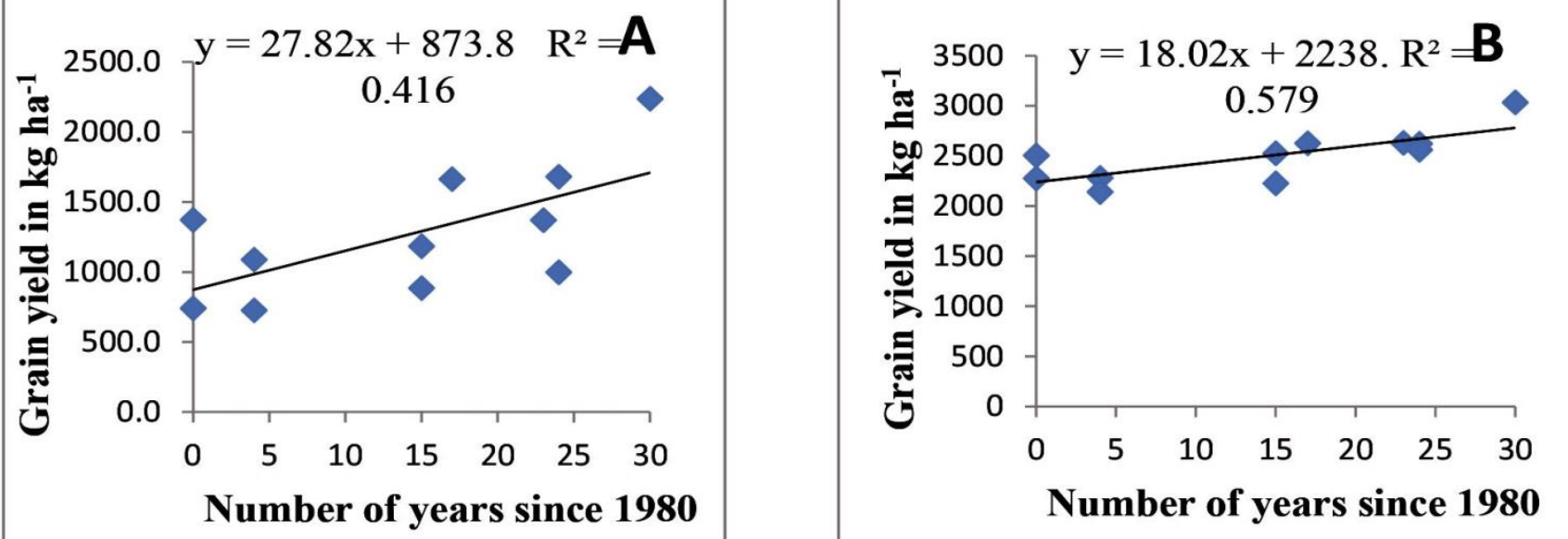

Figure 1: Relationship between the year of cultivar release (the number of years since 1980, the period when the first improved variety released) and Grain yield (A) at DebreZeit, (B) at Enewari

Table 3: Mean performance values of grain yield, biomass yield, harvest index and plant height from separate analysis of variance for lentil varieties grown in the yield potential trial at Debre Zeit and Enewari

\begin{tabular}{|c|c|c|c|c|c|c|c|c|}
\hline \multirow[b]{2}{*}{ Variety ${ }^{a}$} & \multicolumn{5}{|c|}{ Debre Zeit } & \multicolumn{3}{|c|}{ Enewari } \\
\hline & GY & BMY & HI & PLH ${ }^{\circ}$ & GY & $\mathbf{B M}$ & HI & PLH \\
\hline El-142 & $741.2^{c}$ & $2932.5^{c}$ & $0.253^{\mathrm{ab}}$ & 23.4 & $2277.7^{b c}$ & $3999.6^{\mathrm{e}}$ & $0.57^{\mathrm{a}}$ & $26.2^{\mathrm{cd}}$ \\
\hline R-186 & $1372.5^{b}$ & $4416.3^{b}$ & $0.310^{\mathrm{ab}}$ & 29.4 & $2504.4^{b c}$ & $4679.0^{\text {cde }}$ & $0.53^{\mathrm{ab}}$ & $35.4^{\mathrm{a}}$ \\
\hline Chekol & $727.5^{c}$ & $3613.3^{b c}$ & $0.203^{b}$ & 23.3 & $2280.6^{b c}$ & 4911.0 abcd & $0.55^{\mathrm{ab}}$ & $35.6^{\mathrm{a}}$ \\
\hline Chalew & $1089.2^{b c}$ & $3335.4^{b c}$ & $0.330^{\mathrm{ab}}$ & 23.9 & $2140.6^{c}$ & $4113.8^{\mathrm{de}}$ & $0.53^{\mathrm{ab}}$ & $27.0^{\mathrm{abc}}$ \\
\hline Adda & $885.0^{b c}$ & $3491.3^{b c}$ & $0.247^{a b}$ & 24.8 & $2227.9^{b c}$ & 4472.9 cde & $0.50^{b c}$ & $31.8^{\mathrm{abc}}$ \\
\hline Gudo & $1185.0^{b e}$ & $3905.0^{b c}$ & $0.300^{\mathrm{ab}}$ & 27.5 & $2527.3^{b c}$ & $5611.2^{\mathrm{ab}}$ & $0.45^{\mathrm{cd}}$ & $34.2^{a b}$ \\
\hline Alemaya & $1663.4^{a b}$ & $4311.7^{b c}$ & $0.380^{\mathrm{a}}$ & 22.7 & $2626.7^{a b}$ & $5186.7^{a b c}$ & $0.51^{\mathrm{b}}$ & $28.6^{\text {abcd }}$ \\
\hline Assano & $1370.3^{b c}$ & $3890.0^{b c}$ & $0.327^{a b}$ & 25.5 & $2630.4^{a b}$ & $4793.0^{\text {bod }}$ & $0.50^{b c}$ & $25.7^{\mathrm{cd}}$ \\
\hline Alemtena & $998.8^{b c}$ & $3768.4^{b c}$ & $0.257^{a b}$ & 24.2 & $2622.1^{a b}$ & $4860.4^{\text {bod }}$ & $0.54^{a b}$ & $32.9^{a b c}$ \\
\hline Teshale & $1681.3^{\mathrm{ab}}$ & $4711.9^{a b}$ & $0.360^{\mathrm{a}}$ & 22.8 & $2560.9^{b c}$ & 4911.0 abcd & $0.52^{\mathrm{ab}}$ & $24.1^{\mathrm{d}}$ \\
\hline Derso & $2237.9^{a}$ & $5804.6^{a}$ & $0.393 \mathrm{a}$ & 30.4 & $3034.4 \mathrm{a}$ & $5734.6 \mathrm{a}$ & $0.53 \mathrm{ab}$ & $28.0 \mathrm{bcd}$ \\
\hline Mean & 1268.36 & 4016.4 & 0.31 & 25.3 & 2450.21 & 4843.024 & 0.51 & 29.59 \\
\hline CV (\%) & 33.94 & 17.71 & 25.16 & 12.5 & 9.49 & 9.016 & 5.92 & 12.63 \\
\hline
\end{tabular}

${ }^{a}$ Varieties are listed in chronological order from the oldest to the recent

Means followed by a common letter with in a column are not significantly different from each other at $\mathrm{P} \leq 0.05$.

${ }^{\circ}$ No significant differences

Abbreviations: GY- grain yield, BMY- Biomass yield (kg/ha), HI- Harvest index, and PLH-Plant height (cm)

Table 4: Mean square of characters from combined analysis of variance for Lentil varieties grown in the yield potential trials at Debre Zeit and Enewari

\begin{tabular}{|l|c|c|c|c|c|}
\hline \multirow{2}{*}{ Traits } & \multicolumn{5}{|c|}{ Source of Variation } \\
\cline { 2 - 6 } & Location (1) & Error (4) & Variety (10) & L X V (10) & Error (40) \\
\hline Days to flowering & $1256.727^{* *}$ & 8.394 & $118.367^{* *}$ & $20.894^{* *}$ & 2.894 \\
\hline Grain filling period & $706.909^{* *}$ & $3 . .3$ & $24.894^{* *}$ & $29.142^{* *}$ & 4.414 \\
\hline Primary branch & $0.379^{*}$ & 0.115 & 0.127 & $0.139^{*}$ & 0.063 \\
\hline Plant height & $308.535^{* *}$ & 27.815 & $45.653^{* *}$ & 18.321 & 11.978 \\
\hline Hundred seed weight & $3.0501^{* *}$ & 0.12 & $3.899^{* *}$ & $0.156^{*}$ & 0.057 \\
\hline Biomass yield & $12548734.1^{* *}$ & 749013.16 & $2245253.26^{* *}$ & 513122.86 & 348346.01 \\
\hline
\end{tabular}


Table 5: Mean days to flowering, grain filling period, primary branch, plant height, hundred seed weight and Biomass yield from the combined analysis

\begin{tabular}{|c|c|c|c|c|c|c|}
\hline Varieties & $\begin{array}{c}\text { Days to } \\
\text { flowering }\end{array}$ & $\begin{array}{c}\text { Grain Filling } \\
\text { period }\end{array}$ & $\begin{array}{c}\text { Primary } \\
\text { Branch(@) }\end{array}$ & Plant Height & $\begin{array}{c}\text { Hundred } \\
\text { Seed weight }\end{array}$ & Biomass Yield \\
\hline El-142 & $51.50^{\mathrm{d}}$ & $44.17^{\mathrm{dc}}$ & 2.6 & $24.75^{\text {cd }}$ & $2.15^{\mathrm{f}}$ & $3466.1^{\mathrm{e}}$ \\
\hline R-186 & $65.50^{\mathrm{a}}$ & $45.90^{\text {bcd }}$ & 2.52 & $32.40^{\mathrm{a}}$ & $2.43^{\text {ef }}$ & $4547.6^{\text {bed }}$ \\
\hline Chekol & $55.50^{c}$ & $41.50^{\mathrm{e}}$ & 2.55 & $25.15^{\text {cd }}$ & $2.20^{f}$ & $3863.6^{\text {de }}$ \\
\hline Chalew & $57.00^{\mathrm{bc}}$ & $46.00^{\mathrm{bcd}}$ & 2.6 & $27.75^{\text {bed }}$ & $2.63^{\mathrm{e}}$ & $4123.3^{\text {bede }}$ \\
\hline Adaa & $51.67^{\mathrm{d}}$ & $48.83^{\mathrm{a}}$ & 2.52 & $28.30 \mathrm{abc}$ & $4.32^{b}$ & $3982.1^{\text {cde }}$ \\
\hline Gudo & $57.83^{b}$ & $48.33^{\mathrm{ab}}$ & 2.67 & $30.87^{\mathrm{ab}}$ & $3.12^{\mathrm{d}}$ & $4758.1^{\mathrm{bc}}$ \\
\hline Alemaya & $51.83^{d}$ & $46.83 \mathrm{abc}$ & 2.47 & $25.65^{\mathrm{cd}}$ & $3.10^{\mathrm{d}}$ & $4749.2^{\mathrm{bc}}$ \\
\hline Assano & $50.33^{d}$ & $46.00^{\text {bed }}$ & 2.22 & $25.62^{\text {cd }}$ & $4.60^{\mathrm{a}}$ & $4591.5^{\text {bcd }}$ \\
\hline Alemtena & $52.33^{d}$ & $44.00^{\mathrm{d}}$ & 2.58 & $28.53 \mathrm{abc}$ & $3.58^{\mathrm{c}}$ & $4314.4^{\text {bed }}$ \\
\hline Teshale & $51.67^{\mathrm{d}}$ & $45.17^{\mathrm{dc}}$ & 2.45 & $23.47^{\mathrm{d}}$ & $3.53^{c}$ & $4811.5^{\mathrm{b}}$ \\
\hline Derso & $52.50^{d}$ & 46.00 bcd & 2.8 & $29.20 \mathrm{abc}$ & $3.03^{d}$ & $5769.6^{a}$ \\
\hline Mean & 54.3 & 45.69 & 2.54 & 27.43 & 3.15 & 4452.44 \\
\hline $\mathrm{CV}(\%)$ & 3.13 & 4.6 & 9.84 & 12.62 & 7.56 & 13.26 \\
\hline
\end{tabular}

${ }^{\circ}$ No significant differences.

Table 6: Mean values of varieties released in 1980, coefficient of determination (R2), regression coefficients (b) of various agronomic traits, and the annual relative genetic gain (RGG) at Debre Zeit and Enewari

\begin{tabular}{|c|c|c|c|c|c|c|c|c|}
\hline \multicolumn{9}{|c|}{$1980-2010$} \\
\hline \multirow[t]{2}{*}{ Traits } & \multicolumn{4}{|c|}{ Debre Zeit } & \multicolumn{4}{|c|}{ Enewari } \\
\hline & Mean & $\mathbf{R}^{2}$ & $\mathbf{b}$ & $\begin{array}{c}\text { R GG (\% } \\
\left.\mathrm{yr}^{-1}\right)\end{array}$ & Mean & $\mathbf{R}^{2}$ & $\mathbf{b}$ & $\begin{array}{c}\text { RGG (\% } \\
\left.\mathrm{yr}^{-1}\right)\end{array}$ \\
\hline Days to flowering & 55.00 & 40.97 & $-0.359^{*}$ & -0.65 & 62.00 & 15.70 & -0.121 & -0.20 \\
\hline Days to maturity & 96.00 & 13.98 & -0.243 & -0.25 & 111.00 & 11.95 & -0.144 & -0.13 \\
\hline Grain filling period & 41.00 & 9.12 & 0.115 & 0.28 & 48.65 & 1.76 & -0.014 & -0.03 \\
\hline Plant height & 26.40 & 2.43 & 0.039 & 0.15 & 30.80 & 11.02 & -0.129 & -0.42 \\
\hline Primary branch & 2.70 & 0.93 & -0.002 & -0.07 & 2.50 & 1.70 & -0.004 & -0.16 \\
\hline Secondary branch & 20.60 & 1.91 & -0.045 & -0.22 & 9.75 & 19.82 & -0.071 & -0.73 \\
\hline Seed per pod & 1.40 & 25.86 & -0.013 & -0.93 & 1.55 & 68.50 & $-0.014^{* *}$ & -0.90 \\
\hline Pod per plant & 67.63 & 0.00 & -0.007 & -0.01 & 49.15 & 13.02 & -0.299 & -0.61 \\
\hline 100 seed weight & 2.10 & 40.30 & $0.050^{*}$ & 2.38 & 2.49 & 49.18 & $0.053^{*}$ & 2.13 \\
\hline Grain yield & 1056.85 & 41.67 & $27.820^{*}$ & 2.63 & 2391.05 & 57.99 & $18.023^{* *}$ & 0.75 \\
\hline Biomass yield & 3674.40 & 39.85 & $46.168^{*}$ & 1.26 & 4339.30 & 40.70 & $32.303^{*}$ & 0.74 \\
\hline Harvest index & 0.28 & 25.75 & 0.003 & 1.07 & 0.55 & 12.39 & -0.001 & -0.18 \\
\hline Biomass production rate & 37.88 & 54.11 & $0.630^{* *}$ & 1.66 & 39.05 & 63.37 & $0.395^{* *}$ & 1.01 \\
\hline Seed growth rate & 30.31 & 24.06 & 0.510 & 1.68 & & 48.82 & 57.49 & $0.39^{* *}$ \\
\hline
\end{tabular}

b regression coefficient, ${ }^{*},{ }^{* *}$ Significant at probability level of 0.05 and 0.01 , respectively.

\section{Biomass Yield, Harvest Index and Plant Height}

The combined analysis of variance showed non-significant genotype $\mathrm{X}$ location interaction for biomass yield and plant height (Table 4). However, there were highly significant differences between genotypes in biomass yield and plant height (Table 5). The recently released variety, Derso, provide significantly the highest biomass yield of 5769.6 $\mathrm{kg} \mathrm{ha}^{-1}$ than all the other varieties (Table 5). The highest harvest index value among the varieties was recorded for the varieties, Derso (0.393) and EL-142 (0.57), at Debre Zeit and Enewari respectively (Table 3). 
The changes in biomass yield over the time of variety release were adequate and are described by the equation: $\mathrm{y}=$ $46.16 x+3361$ at Debre Zeit and $y=32.3 x+4384$.

Regression analysis between harvest index and years of release of cultivars showed no significant change $(\mathrm{P}<0.05)$ (Table 6) in both locations. Even though there was a significance difference $(\mathrm{P}<0.05)$ between genotypes means for plant height at Enewari (Table 2), there was no a clear difference between the older varieties and the recently released once (Table 3). As it was estimated from regression of variety means for plant height against year of release, a non-significant 0.039 and -0.129 $\mathrm{cm} \mathrm{yr}^{-1}$ annual rate of gain was recorded at Debre Zeit and Enewari respectively (Table 6).

\section{Yield components}

The separate analysis of variance for number of seed per pod and pods per plant revealed significant $(\mathrm{P}<0.05)$ difference among varieties at both locations except number of seeds per pod at Debre Zeit (Table 2). At Debre Zeit, only the recently released variety 'Derso 'gave a significant $(\mathrm{P}<0.05)$ higher pod per plant than Adaa, Gudo, Assano, and Teshale (Table 7). Whereas, at Enewari, varieties R-186, Chekol and Derso gave significant higher yield than Adaa, Gudo, and Alemtena (Table 8).

The mean number of seeds per pod at Enewari ranged from 1.13 seeds per pod for the variety 'Teshale' to 1.63 seeds per pod to the variety EL-142 (Table 8). However, this small difference in mean seeds per pods represented a significant $(\mathrm{P}<0.05)$ decrease with $0.910 \% \mathrm{yr}^{-1}$ relative genetic gain at Enewari and a non-significant $0.931 \% \mathrm{yr}^{-1}$ decrease at Debre Zeit (Table 6). This indicates that lentil yield improvement involved a decrement in seed per pod.

\section{Phenological Traits}

The combined analyses of variance across the two test locations showed significant $(\mathrm{P}<0.05)$ differences among varieties, locations, and location by variety interaction for days to flowering and grain filling period (Table 4). The Analysis of variance of the Phenological traits at individual environment revealed that there was significant difference $(P<0.01)$ among varieties in days to flowering, and days to maturity in the two environments and only at Debre Zeit for grain filling period (Table 2). Most of the recently released varieties were the earliest in flowering. Variety R-186 is the variety that took a long period to flower and mature, and the highest yielding variety 'Derso' is among the varieties that flower and mature early (Table 5). Genotypes were observed to flower and mature early at Debre Zeit $(48,92.4)$ and late to flower and mature at Enewari $(58.7,107.7)$ respectively (Table 7 and 8). The regression analysis of days to flowering against the year of release indicated a significant annual genetic gain of 0.359 days $\mathrm{yr}^{-1}$ at Debre Zeit and a non-significant -0.112 days $\mathrm{yr}^{-1}$ gain at Enewari. Also, days to physiological maturity showed a non-significant negative trend with the year of variety release in both locations (Table 6). The relative annual genetic gain since 1980 was found to be 19.5\% (Debre Zeit) and $6 \%$ (Enewari) for days to flowering and $7.5 \%$ (Debre Zeit) and 3.9\% (Enewari) for physiological maturity in lentil.

Table 7: Mean performance of characters from separate analysis of variance for lentil varieties grown in the yield potential trial at Debre Zeit

\begin{tabular}{|c|c|c|c|c|c|c|c|c|c|c|}
\hline Variety $^{2}$ & $\begin{array}{l}\text { Days to } \\
\text { flowering }\end{array}$ & $\begin{array}{l}\text { Days to } \\
\text { maturity }\end{array}$ & $\begin{array}{l}\text { Grain } \\
\text { filling } \\
\text { period }\end{array}$ & $\begin{array}{c}\text { Primary } \\
\text { branch } \\
\text { (no.) }\end{array}$ & $\begin{array}{c}\text { Secondary } \\
\text { branch } \\
\text { (no.) }\end{array}$ & $\begin{array}{l}\text { Seed per } \\
\text { pod }\end{array}$ & $\begin{array}{c}\text { Pods per } \\
\text { plant }\end{array}$ & $\begin{array}{c}\text { Hundred } \\
\text { seeds } \\
\text { weight }\end{array}$ & \begin{tabular}{|c|} 
Biomass \\
production \\
rate \\
\end{tabular} & $\begin{array}{c}\text { Seed } \\
\text { growth } \\
\text { rate }\end{array}$ \\
\hline El-142 & $46.0^{c}$ & $86.33^{c}$ & $40.3^{c}$ & $2.7^{\mathrm{ab}}$ & $18.93^{\mathrm{abc}}$ & 1.43 & $81.3^{\mathrm{ab}}$ & $1.8^{8}$ & $33.96^{c}$ & $18.50^{c}$ \\
\hline R-186 & $64.0^{\mathrm{a}}$ & $105.67^{a}$ & $41.7^{c}$ & $2.7^{a b}$ & $22.33^{a}$ & 1.43 & $53.9^{a b c}$ & $2.4^{\text {ef }}$ & $41.80^{b c}$ & $42.91^{b c}$ \\
\hline Chekol & $52.7^{c}$ & $86.67^{c}$ & $34.0^{\mathrm{d}}$ & $2.7^{\mathrm{ab}}$ & $20.13^{\mathrm{ab}}$ & 1.80 & $56.2 \mathrm{abc}$ & $1.9^{\mathrm{fg}}$ & $41.66^{b c}$ & $21.45^{c}$ \\
\hline Chalew & $56.3^{b}$ & $98.00^{\mathrm{b}}$ & $41.7^{c}$ & $2.7 \mathrm{ab}$ & $22.07 \mathrm{a}$ & 1.80 & $50.1 \mathrm{abc}$ & $2.5^{\mathrm{de}}$ & $33.84^{c}$ & $25.91 \mathrm{bc}$ \\
\hline Adda & $47.3^{c}$ & $94.67^{b}$ & $47.3^{\mathrm{ab}}$ & $2.4^{b c}$ & $13.6 \mathrm{~b}^{\mathrm{c}}$ & 1.03 & $26.9^{c}$ & $3.9^{\mathrm{b}}$ & $36.72^{c}$ & $18.33^{c}$ \\
\hline Gudo & $53.0^{c}$ & $103.0^{\mathrm{a}}$ & $50.0^{a}$ & $2.5^{b c}$ & $19.67 \mathrm{ab}$ & 1.47 & $42.5^{b c}$ & $3.0^{\mathrm{cd}}$ & $38.01^{b c}$ & $23.92^{b c}$ \\
\hline Alemaya & $46.0^{c}$ & $89.67^{c}$ & $43.7^{b c}$ & $2.6^{b c}$ & 17.53 abc & 1.03 & $66.2^{a b c}$ & $2.8^{\text {cde }}$ & $48.11^{b c}$ & $38.60^{\mathrm{ab}}$ \\
\hline Assano & $44.3^{c}$ & $87.67^{c}$ & $43.3^{b c}$ & $2.1^{c}$ & $12.67^{c}$ & 1.43 & $35.5^{c}$ & $4.7^{\mathrm{a}}$ & $44.27^{b c}$ & $34.97 \mathrm{bc}$ \\
\hline Alemtena & $47.0^{\mathrm{c}}$ & $87.00^{c}$ & $40.0^{\mathrm{c}}$ & $2.7 \mathrm{ab}$ & $20.00^{\mathrm{ab}}$ & 1.10 & $59.9 \mathrm{abc}$ & $3.2^{c}$ & $43.31^{\mathrm{bc}}$ & $27.06^{b c}$ \\
\hline Teshale & $45.7^{c}$ & $87.67^{c}$ & $42.0^{c}$ & $2.4^{b c}$ & $20.17 \mathrm{ab}$ & 1.17 & $42.7^{b c}$ & $3.1^{c}$ & $53.87 \mathrm{ab}$ & $40.15^{\text {b }}$ \\
\hline Derso & $47.3^{c}$ & $90.00^{c}$ & $42.7^{\mathrm{c}}$ & $3.1^{\mathrm{a}}$ & $24.07^{\mathrm{a}}$ & 1.43 & $90.3^{\mathrm{a}}$ & $2.8^{\mathrm{cde}}$ & $64.48^{a}$ & $52.31^{a}$ \\
\hline Mean & 50 & 92.39 & 42.4 & 2.6 & 19.2 & 1.38 & 55.05 & 2.9 & 43.64 & 29.9 \\
\hline CV (\%) & 3.07 & 2.44 & 5.94 & 10.4 & 18.05 & 33.3 & 38.14 & 9.75 & 17.77 & 34.5 \\
\hline
\end{tabular}

${ }^{a}$ Varieties are listed in chronological order from the oldest to the recent 
Means followed by a common letter with in a column are not significantly different from each other at $\mathrm{P} \leq 0.05$ according to Duncan's Multiple Range Test

\section{Productivity traits}

The Analysis of variance for biomass production rate and seed growth rate at individual environments revealed that there were significant differences $(\mathrm{P}<0.05)$ among varieties in the two traits in both of the environments $($ Table 2$)$. Genotypes were observed to produce smaller biomass production rate and seed growth rate at Debre Zeit (43.6; 30 $\mathrm{kg} \mathrm{ha}^{-1}$ day $^{-1}$ ) compared to at Enewari $\left(45.4 ; 51 \mathrm{~kg} \mathrm{ha}^{-1}\right.$ day $^{-1}$ ) (Table 7 and 8). Most of the recently released varieties provide a higher biomass production rate and seed growth rate than the older varieties in both locations (Table 7 and 8). Our data indicated that, biomass production rate and Seed growth rate from the 30 years of plant breeding and selection in lentil was increased by $49.8 \%$ and $50.4 \%$ at Debre Zeit and $30.3 \%$ and $24 \%$ at Enewari, respectively. The annual genetic gain as estimated from the regression coefficient was 0.63 and $0.50 \mathrm{~kg} \mathrm{ha}^{-1}$ day $^{-1}$ at Debre Zeit and 0.395 and $0.39 \mathrm{~kg} \mathrm{ha}^{-1}$ day $^{-1}$ at Enewari for biomass production rate and seed growth rate respectively (Table 6).

Table 8: Mean performance of characters from separate analysis of variance for lentil varieties grown in the yield potential trial at Enewari

\begin{tabular}{|c|c|c|c|c|c|c|c|c|c|c|}
\hline Variety & $\begin{array}{l}\text { Days to } \\
\text { flowering }\end{array}$ & $\begin{array}{l}\text { Days to } \\
\text { maturity }\end{array}$ & $\begin{array}{l}\text { Grain } \\
\text { filling } \\
\text { period }\end{array}$ & $\begin{array}{c}\text { Primary } \\
\text { branch } \\
\text { (no.) }\end{array}$ & $\begin{array}{l}\text { Secondary } \\
\text { branch } \\
\text { (no.) }\end{array}$ & $\begin{array}{c}\text { Seed per } \\
\text { pod }\end{array}$ & $\begin{array}{c}\text { Pods per } \\
\text { plant }\end{array}$ & $\begin{array}{c}\text { Hundred } \\
\text { seeds } \\
\text { weight }\end{array}$ & $\begin{array}{c}\text { Biomass } \\
\text { production } \\
\text { rate }\end{array}$ & $\begin{array}{c}\text { Seed } \\
\text { growth } \\
\text { rate }\end{array}$ \\
\hline EL-142 & $57.0^{c}$ & $105.0^{\mathrm{g}}$ & 48.0 & 2.7 & $7.7^{\mathrm{d}}$ & $1.63^{\mathrm{a}}$ & $45.0^{\text {abc }}$ & $2.47^{d}$ & $38.11^{e}$ & $47.48^{\text {bed }}$ \\
\hline R-186 & $67.0^{a}$ & $117.0^{\mathrm{a}}$ & 49.3 & 2.3 & $11.8^{\mathrm{a}}$ & $1.47^{\text {abcd }}$ & $53.3^{a}$ & $2.50^{\mathrm{d}}$ & $39.99 \mathrm{de}$ & $50.16^{\text {bcd }}$ \\
\hline Chekol & $57.7^{c}$ & $108.0^{b c}$ & 50.3 & 2.7 & $9.0 \mathrm{bc}$ & $1.57 \mathrm{abc}$ & 41.0 abcd & $2.73^{d}$ & 45.47 bede & $42.53^{d}$ \\
\hline Chalew & $58.3^{c}$ & $107.3^{\text {de }}$ & 49.0 & 2.0 & $7.7^{\mathrm{d}}$ & $1.60 \mathrm{abc}$ & $53.2^{\mathrm{a}}$ & $2.50^{\mathrm{d}}$ & $38.33^{e}$ & $46.54^{b c d}$ \\
\hline Adaa & $56.0^{c}$ & $106.3^{\text {defg }}$ & 50.3 & 3.0 & $6.3^{e}$ & $1.17^{\mathrm{d}}$ & $30.2^{\mathrm{dc}}$ & $4.73^{a}$ & 42.04 cde & $44.24^{\text {cd }}$ \\
\hline Gudo & $62.7^{b}$ & $109.3^{b}$ & 46.6 & 2.7 & $9.3^{b}$ & $1.33^{a b o d}$ & $33.1^{\text {bod }}$ & $3.26^{c}$ & 51.39 a b & $54.29^{a b}$ \\
\hline Alemaya & $57.7^{c}$ & $107.7^{\mathrm{cd}}$ & 50.0 & 2.3 & $6.7^{e}$ & $1.27^{b c d}$ & $46.9^{a b}$ & $3.43^{c}$ & $48.17^{a b c}$ & $52.57^{\mathrm{abc}}$ \\
\hline Assano & $56.3^{c}$ & $105.0 \mathrm{~s}$ & 48.7 & 2.0 & $9.0^{b c}$ & $1.23 \mathrm{~cd}$ & 37.1 abed & $4.50^{\mathrm{a}}$ & $50.41 \mathrm{~b}$ & 53.86 ab \\
\hline Alemtena & $57.7^{c}$ & 105.7 fg & 48.0 & 2.3 & $6.3^{e}$ & 1.37 abcd & $28.4^{\mathrm{d}}$ & $3.97^{b}$ & 45.99 abode & $54.81^{\mathrm{ab}}$ \\
\hline Teshale & $57.7^{c}$ & $106.0^{\mathrm{efg}}$ & 48.3 & 2.7 & $6.3^{e}$ & $1.13^{\mathrm{d}}$ & $44.6^{\mathrm{abc}}$ & $3.90^{\mathrm{b}}$ & $46.35^{\text {abcd }}$ & $53.06^{\mathrm{abc}}$ \\
\hline Derso & $57.7^{\mathrm{c}}$ & $107.0^{\text {cdef }}$ & 49.3 & 2.3 & $8.3^{\mathrm{cd}}$ & $1.23^{\mathrm{cd}}$ & $49.6^{\mathrm{a}}$ & $3.23^{c}$ & $53.59^{\mathrm{a}}$ & $61.53^{\mathrm{a}}$ \\
\hline Mean & 58.7 & 107.7 & 49.0 & 2.47 & 8.1 & 1.3636 & 42.04 & 3.385 & 45.44 & 50.0 \\
\hline $\mathrm{CV}$ & 3.154 & 0.718 & 3.21 & 9.16 & 5.69 & 13.407 & 20.27 & 5.32 & 9.15 & 9.46 \\
\hline
\end{tabular}

\section{Association of grain yield and agronomic traits}

Grain yield was significantly $(r=0.79, P<0.01)$ and positively correlated with biomass yield, whereas it was nonsignificantly associated with harvest index at Enewari (Data not shown). In addition the Productive Traits showed significant association with grain yield at $P<0.01$. All phenological and other yields related traits showed a nonsignificant association with grain yield. At Debre Zeit biomass yield $(r=0.93)$, harvest index $(r=0.88)$, biomass production rate $(r=0.91)$ and seed growth rate $(r=0.94)$ showed a significant and positive correlation with grain yield (Data not shown).

\section{Discussion}

The average rate of increase in grain yield potential per year of release over the 30 year period was $27.82 \mathrm{~kg} \mathrm{ha}^{-1}$ at Debre Zeit and 18.02 at Enewari. The higher rate of annual increase at Debre Zeit may be due to the selection of the materials in early stages of selections (Screening Nursery Stage I and II, and Preliminary National Variety Trial) at Debre Zeit. The annual genetic gain obtained at Debre Zeit was comparable to the $27.16 \mathrm{~kg} \mathrm{ha}^{-1} \mathrm{yr}^{-1} \mathrm{improvement}$ reported in teff (Yifru and Hailu, 2005) and to the $26.8 \mathrm{~kg} \mathrm{ha}^{-1} \mathrm{yr}^{-1}$ genetic progress in late maturity group soybean in

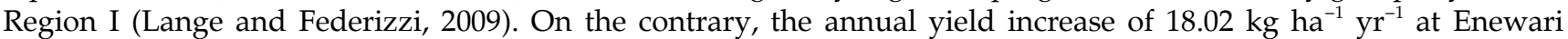
attributed to genetic improvement in the present study was approximately similar in magnitude to the $18.1 \mathrm{~kg}^{-1}$ $\mathrm{yr}^{-1}$ (in Region IV) and $18.5 \mathrm{~kg} \mathrm{ha}^{-1} \mathrm{yr}^{-1}$ (in Region II) improvement for soybean yield of medium and late maturing types, respectively, obtained in Rio Grande do Sul, Brazil Lange and Federizzi, 2009); and $17.7 \mathrm{~kg} \mathrm{ha}^{-1} \mathrm{yr}^{-1}$ in wheat in Western Siberia (Morgounov et al., 2010). 
The results of the present study indicated that the lentil yield improvement program that employed selection from introductions as major breeding methods was successful in improving grain yield. It can also be seen by considering the released varieties from the selection of local collection and introduced materials, which there was a consistent yield improvement over the consecutive decades. This demonstrates that grain yield potential of lentils has not attained plateau in Ethiopia; indicating the opportunity of further increasing grain yield through the same breeding methods. Based on their seed size all the varieties in the present study are small to medium seed sized lentil that varies between $1.80 \mathrm{gm}$ and $4.73 \mathrm{gm}$ per 100 seed weight. Small seeded-lentils are graded, decorticated and split before marketing. Seed size is one of the most important quality characteristics of small-seeded lentils since it affects the pattern of decortications (Erskine et al., 1985). Accordingly within the limits of the size of small seeded lentils, the larger the seed, the lower is the percentage loss during decortications (Erskine et al., 1985). Hence, the significant increase in hundred seed weight obtained with the release of new varieties in the present study indicates the effort made by lentil breeders in improving the recovery \% at decortications.

Similar to that reported by Erskine (1983) for the world lentil collection grown in Syria and Whitehead et al. (2000), a strong positive correlation of grain yield with biomass yield $\left(r=0.93^{* *}\right)$ and harvest index $\left(r=0.91^{* *}\right)$ were found at Debre Zeit (Data not shown). According to this result, biomass yield and harvest index should be considered as a selection criteria for the breeding program to increase yield. These results are in agreement with the findings of other researchers (Anjam et. al., 2005; Salehi, 2008; Karadavut, 2009). Similarly, Iqbal et al. (2010) and Jin et al. (2010) reported highly significant positive correlations of grain yield with biomass yield and harvest index in soybean.

Biomass production and seed growth rate showed a highly significant $(\mathrm{P} \leq 0.01)$ positive relation with grain yield (Data not shown). This clearly showed that improvement in these traits was markedly concurrent to the yield improvement achieved in the past and can be further exploited in future breeding. In a similar study, Kebere et al. (2006) on haricot bean found a positive correlation between grain yield and each of these traits. Likewise, De Bruin and Pedersen (2009) found a positive relation between grain yield and crop growth rate during seed set.

In this study at Debre Zeit, changes in lentil yield potential were strongly correlated with biomass yield and harvest index indicating progressive improvement in biomass yield and harvest index was successful in developing varieties which are efficient in accumulation and partitioning of dry matter to increase yield. Conversely, at Enewari improvement in seed growth rate and grain filling period are responsible for increasing grain yield. Generally, the results showed that the agro-morphological basis of an improvement in grain yield of lentil can be used as a guide to further increase gains both from the changes that have already taken place and that have not. It seems strategically advisable that the national lentil improvement programme in the future should give due attention to the high altitude areas and as well in developing early varieties.

\section{ACKNOWLEDGMENTS}

We would like to express our gratitude to Amhara Agricultural research institute and Debre Birhan agricultural research center for its financial support. We are grateful for the assistances provided by the research and technical staff of the Highland pulse improvement program of Debre Birhan and Debre Zeit Agricultural Research Center.

\section{REFERENCES}

Amsal Tarekegne, D.G. Turner and Getinet Gebeyehu, 1995b. Improvement in durum wheat yield and associated effects on morpho-physiological characters. African Crop Science Journal, 3(4): 433-442.

Amsal Tarekegne, D.G. Turner, and Getinet Gebeyehu, 1995a. Improvement in yield of bread wheat cultivars released in Ethiopia from 1949 to 1987. African Crop Science Journal, 3(1): 41-49.

Anjam, M., A. Ali, SH. Iqbal, and A. Haqqani, 2005. Evaluation and Correlation of Economically Important Traits in Exotic Germplasm of Lentil. International Journal of Agricultural Biology, 7(6): 959-961.

CSA, 2010. Area and production of crops. (Private peasant holdings, Meher Season). V 1. Statistical Bulletin 446. Addis Ababa, Ethiopia.

De Bruin, J. and P. Pedersen, 2009. Growth, yield, and yield component changes among old and new soybean cultivars. Agronomy journal, 101: 124-130.

Erskine, W., 1983. Relationship between the yield of seed and straw in lentil. Field Crops Research, 7: 115-121.

Erskine, W., 2009. Global Production, Supply and Demand. pp. 4-12. In: Erskine W., J. Muehlbauer, A. Sarker and B. Sharma (eds.). The Lentil Botany, Production and Uses. CAB International.

Erskine, W., P.C. Williams and H. Nakkoul, 1985. Genetic and environmental variation in the seed size, protein, yield and cooking quality of lentils. Field Crops Research, 12: 153-161.

Gomez, K. and A. Gomez, 1984. Statistical Procedure for Agricultural Research. $2^{\text {nd }}$ ed. International Rice Research Institute. John Wiley and Sons Inc. 680p. 
Grusak, A., 2009. Nutritional and Health beneficial Quality. pp. 368-390. In: Erskine W., J. Muehlbauer, A. Sarker and B. Sharma (eds.). The Lentil Botany, Production and Uses. CAB International.

Heisey, P.W., M.A. Lantican, and H.J. Dubin, 2002. Impacts of international wheat breeding research in developing countries, 196697. Mexico, D.F. CIMMYT. Institute Inc., Cary, NC, USA.

Iqbal, Z., M. Arshad, M. Ashraf, R. Naeem, M. Malik, and A. Waheed, 2010. Genetic divergence and correlation studies of soybean [Glycine max (L.) Merrill.] genotypes. Pakistan Journal of Botany, 42: 971-976.

Jin, J., X. Liu, G. Wang, L. Mi, Z. Shen, X. Chen, and S. Herbert, 2010. Agronomic and physiological contributions to the yield improvement of soybean cultivars released from 1950 to 2006 in Northeast China. Field Crops Research, 115: 116-123.

Karadavut, U., 2009. Path analysis for yield and yield components In lentil (Lens culinaris Medik.). Turkish Journal of Field Crops, 14(2): 97-104.

Kebere Bezaweletaw, Ketema Belete, and S. Prapa, 2006. Genetic gain in grain yield and associated agronomic traits in haricot bean (Phaseolu vulgaris L.). Kasetsart, 40: 835-847.

Lange, C. and L. Federizzi, 2009. Estimation of soybean genetic progress in the South of Brazil using multi-environmental yield trials. Scientia Agricola, 66: 309-316.

Morgounov, A., V. Zykin, I. Belan, L. Roseeva, Yu. Zelenskiy, H.F. Gomez-Becerra, H. Budak, and F. Bekes, 2010. Genetic gains for grain yield in high latitude spring wheat grown in Western Siberia in 1900-2008. Field Crops Research, 117: 101-112.

Salehi, M., A, Haghnazari, F. Shekari, and F. Faramarzi, 2008. The Study of Seed Yield and Yield Components of Lentil (Lentil culinaris Medik) under Normal and Drought Stress Condition. Pakistan Journal of Biological Science, 11(5): 758-762.

Sarker, A., R.K. Neupane, B. Sakr, F. El Ashkar, A. Lutfir, and W. Erskine, 2002. More Gain From Less Rain: ICARDA's Strategy to Improve Lentil for Resource Poor Farmers in Dry Areas, CARAVAN, issue number 17, December 2002.

SAS Institute, 2004. SAS /STAT Guide for personal computers, version 9.1 editions. SAS

Shewry, P.R. and N. Halford, 2002. Cereal seed storage proteins: structures, properties and role in grain utilization. Journal of Experimental Botany, 53: 947-958.

Waddington, S., S. Ransom, M. Osamanzi, and D. Sounders, 1986. Improvement in the yield potential of bread wheat adapted to North West Mexico. Crop Science, 26: 699-703.

Whitehead, S. j., R. J. Summerfield, F. J. Muehlbauer, C. J. Coyne, R. H. Ellis, and T. R. Wheeler., 2000. Accumulation and partitioning of biomass and nitrogen in lentil. Crop Science, 40:110-120.

Yifru Teklu and Hailu Tefera, 2005. Genetic improvement in grain yield potential and associated agronomic traits of tef (Eragrostis tef). Euphytica, 114: 247-254. 
